\title{
KARAKTERISASI BAKTERI ANTI QUORUM SENSING (AQS) SEBAGAI PENGHAMBAT VIRULENSI PENYAKIT PADA IKAN LELE DUMBO (Clarias gariepinus)
}

\author{
Hessy Novita")\#, Iman Rusmana"), Munti Yuhana"), dan Fachriyan Hasmi Pasaribu" \\ "Departemen Biologi-FMIPA, Institut Pertanian Bogor \\ ") Departemen Budidaya Perairan-FPIK, Institut Pertanian Bogor \\ Departemen Ilmu Penyakit Hewan-FKH, Institut Pertanian Bogor \\ - Instalasi Penelitian dan Pengembangan Pengendalian Penyakit Ikan
}

(Naskah diterima: 2 Februari 2015; Revisi final: 5 Maret 2015; Disetujui publikasi: 11 Maret 2015)

\begin{abstract}
ABSTRAK
Penyakit bakterial adalah salah satu penyebab kerugian besar di bidang akuakultur. Faktor virulensi bakteri penyakit umumnya diekspresikan oleh gen-gen virulen yang diregulasi dengan sistem Quorum Sensing. Tujuan dari penelitian ini adalah untuk mendapatkan isolat bakteri yang memiliki potensi sebagai Anti Quorum Sensing (AQS) yang dapat menghambat faktor virulensi bakteri patogen penyebab penyakit pada ikan lele dumbo (Clarias gariepinus). Isolasi bakteri dilakukan dari sedimen, organ pencernaan dan air kolam ikan lele dumbo dari Parung, Ciampea, dan Gunung Sindur, Bogor, Jawa Barat. Sebanyak 347 isolat bakteri berhasil diisolasi, dan sebanyak $68(19 \%)$ isolat di antaranya mempunyai aktivitas AQS dengan empat isolat yang berpotensi sebagai bakteri AQS yaitu: TS 1 dan TS 2, TA 23, dan TY 33. Empat isolat tersebut teridentifikasi berdasarkan sekuen 16S rRNA sebagai Bacillus amyloliquefaciens, Lysinnibacillus sphaericus, Lysinnibacillus fusiformis, dan Bacillus cereus dengan persentase kemiripan masing-masing 93\%, 99\%, dan 100\%. Berdasarkan analisa gen AHL (Acyl Homoserine Lactone) laktonase (aiiA), keempat isolat tersebut menghasilkan enzim AHL. Hasil studi ini menunjukkan bahwa isolat bakteri hasil isolasi dari kolam ikan lele dumbo dapat menghambat mekanisme Quorum Sensing bakteri patogen ikan dengan mendegradasi autoinduser-nya yang berupa AHL.
\end{abstract}

\footnotetext{
KATA KUNCI: Anti Quorum Sensing (AQS), 16S rRNA, AHL (Acyl Homoserine Lactone) laktonase, Clarias gariepinus
}

ABSTRACT: Characterization of Anti Quorum Sensing bacteria as virulence inhibitor of disease isolated from fish of Clarias gariepinus. By: Hessy Novita, Iman Rusmana, Munti Yuhana, and Fachriyan Hasmi Pasaribu

\begin{abstract}
Bacterial diseases are one of the main problem in damaging the health of aquaculture system. Virulent factors of the bacterial pathogens are generally encoded by virulent genes. Gene expression of virulent are regulated by Quorum Sensing system. This research aimed to obtain bacterial isolates that have potential as Anti Quorum Sensing (AQS) in inhibiting pathogenic bacteria virulence factors which cause disease in catfish (Clarias gariepinus). Catfish samples were obtained from Parung, Ciampea, and Gunung Sindur, Bogor, West Java. The bacteria were isolated from pond sediment, digestive organ and pond water. There were 347 bacterial isolates were successfully isolated, and 68 (19\%) isolates of them had AQS activity. There were four isolates namely TS 1 and TS 2, TA 23 and TY 33 having high AQS activity. Based on the 16S rRNA gene sequences analysis, the isolates were identified as Bacillus amyloliquefaciens, Lysinnibacillus sphaericus, Lysinnibacillus fusiformis and Bacillus cereus with similarity index of 93\%, 99\%, and $100 \%$ respectively. Furthermore, aiiA genes analysis indicated that the isolates had AHL (Acyl Homoserine Lactone)lactonase enzyme.
\end{abstract}

KEYWORDS: $\quad$ Anti Quorum Sensing (AQS), 16S rRNA, AHL (Acyl Homoserine Lactone) lactonase, Clarias gariepinus

\# Korespondensi: Departemen Biologi-FMIPA, Institut

Pertanian Bogor. Jl. Lingkar Kampus, Kampus IPB Dramaga,

Bogor 16680, Jawa Barat, Indonesia

E-mail: hesta_biotek@yahoo.com 


\section{PENDAHULUAN}

Pada budidaya ikan lele, serangan penyakit adalah salah satu kendala yang sering dihadapi oleh pembudidaya. Penyakit dapat muncul di suatu perairan akibat ketidakseimbangan antara lingkungan, ikan, dan jasad patogen. Penanganan dalam budidaya yang kurang baik dapat menyebabkan ikan mengalami stres, sehingga daya tahan tubuhnya menurun dan mudah terserang penyakit (Darshanee et al., 2011). Antibiotika sering digunakan dalam jumlah besar untuk menghindari tingginya mortalitas dan kejadian penyakit bakteri dalam budidaya ikan. Namun, penggunaan antibiotika dapat mengganggu keberadaan komunitas mikrobiota usus maupun perairan dan memicu populasi bakteri yang resisten, serta dikhawatirkan ada efek jangka panjang bagi kesehatan masyarakat. Pendekatan biomolekuler yang belum banyak menjadi perhatian dalam pencegahan dan mengontrol penyakit ikan yaitu penghambatan ekspresi dari gen yang menyandikan faktor virulensinya. Ekspresi gen ini diregulasi dengan sinyal komunikasi antar sel bakteri yang dikenal sebagai Quorum Sensing (QS) (Dong et al., 2007; Defoirdt et al., 2004).

Quorum Sensing merupakan suatu proses yang memungkinkan bakteri dapat berkomunikasi dengan mensekresikan molekul sinyal yang disebut autoinducer atau molekul sinyal biokimia untuk proses komunikasi antar sel. Proses ini memungkinkan suatu populasi bakteri dapat mengatur ekspresi gen tertentu. Konsentrasi autoinducer di lingkungan sebanding dengan kelimpahan sel bakteri yang ada dengan mendeteksi autoinducer, sehingga suatu bakteri mampu mendeteksi keberadaan sel bakteri lain di lingkungannya (Taga et al., 2001).

Untuk menekan pertumbuhan bakteri patogen pada budididaya ikan lele diperlukan bakteri yang berfungsi melakukan peran mekanisme penghambatan terhadap faktor virulensi yaitu dengan menganggu sistem Quorum Sensing yang dikenal dengan Anti Quorum Sensing (AQS) atau Quorum Quenching (QQ). Aplikasi bakteri yang menghasilkan Quorum Quenching sudah banyak diteliti pada akuakultur (Chu et al., 2011; Defoirdt et al., 2004; Defoirdt et al., 2008) seperti: Halogenated furanones dari alga merah laut Delisea pulchra (Manefield et al., 1999) melindungi rotifers, Artemia, dan rainbow trout dari vibrio (Defoirdt et al., 2006; Rasch et al., 2004). Demikian pula Furanon yang mempunyai kesamaan struktur dengan molekul AHL (Acyl Homoserine Lactone) yang mengikat protein LuxR (Manefield et al., 1999) dan terdapat seperti pada $V$. harveyi (Henke \& Bassler, 2004). Recombinant AHL lactonase dari Bacillus sp., yang disuntikkan dengan patogen ikan Aeromonas hydrophila pada ikan mas, dapat menurunkan angka kematian ikan (Chen et al., 2010). Actinobacteria Streptomyces albus mampu mengurangi pembentukan biofilm dan menghambat sistem Quorum Sensing dari Vibrio harveyi, Vibrio vulnificus, dan Vibrio anguillarum (You et al., 2007).

Bakteri Quorum Sensing dapat diisolasi dari lingkungan budidaya ikan lele yang memiliki kesesuaian habitat, baik dengan patogen maupun ikan. Pada penelitian ini, dikarakterisasi isolat bakteri yang memiliki potensi sebagai Anti $Q S$ atau QQ (Quorum Quenching) untuk menghambat faktor virulensi bakteri patogen yang menyebabkan penyakit pada ikan lele. Hasil penelitian ini ke depan diharapkan dapat diaplikasikan sebagai kandidat probiotik atau agen biokontrol pada budidaya ikan lele.

\section{BAHAN DAN METODE}

Sampling. Bakteri AQS diisolasi dari organ pencernaan, sedimen, dan air kolam pemeliharaan ikan lele dumbo (Clarias gariepinus). Ikan lele diperoleh dari pembudidaya di sekitar daerah sentra budidaya sekitar Bogor yaitu: di Parung, Ciampea, dan Gunung Sindur Provinsi Jawa Barat, Indonesia.

Isolasi bakteri Anti Quorum Sensing (AQS). Ikan lele dibedah secara aseptik dan organ pencernaan diletakkan pada cawan steril dan dibilas dengan larutan garam fisiologis steril $(\mathrm{NaCl} 0,85 \% \mathrm{pH} \mathrm{7,4)}$. Bagian usus ditimbang sebanyak 1 gram, dihomogenasi dengan $9 \mathrm{~mL}$ larutan garam fisiologis steril. Pengenceran berseri dilakukan dari $10^{2}$ sampai $10^{10}$ pada media LB (triptone $10 \mathrm{~g}, \mathrm{NaCl} 10 \mathrm{~g}$, yeast extract $5 \mathrm{~g}$, aquades $950 \mathrm{~mL}$ ). Sebanyak $100 \mu \mathrm{L}$ larutan tersebut disebar pada media LA (triptone $10 \mathrm{~g}, \mathrm{NaCl} 10 \mathrm{~g}$, yeast extract $5 \mathrm{~g}$, aquades $950 \mathrm{~mL}$, agar $15 \mathrm{~g}$ ) dan diinkubasi pada suhu $28^{\circ} \mathrm{C}$ selama dua hari. Koloni bakteri yang tumbuh dipilih berdasarkan perbedaan morfologi (ukuran, warna, dan bentuk).

Pada sampel tanah dan air kolam juga dilakukan isolasi bakteri QQ, yaitu sebanyak 1 gram tanah dilarutkan ke dalam $9 \mathrm{~mL}$ garam fisiologis steril 0,85\% dan dibuat pengenceran berseri. Sisa suspensi dipanaskan selama sepuluh menit pada suhu $80^{\circ} \mathrm{C}$. Sebanyak $0,1 \mathrm{~mL}$ dari setiap pengenceran dan suspensi yang dipanaskan tersebut masing-masing disebarkan ke media LA (Luria Agar), kemudian diinkubasi selama dua hari pada suhu ruang. Koloni tunggal dipurifikasi pada media LA untuk mendapatkan isolat bakteri yang murni.

Selanjutnya isolat dari organ pencernaan, tanah dan air kolam pemeliharaan dilakukan purifikasi berulang-ulang dengan media yang sama hingga diperoleh koloni tunggal dan seragam. Isolat murni selanjutnya diperbanyak, sebagian isolat dibuat kultur 
stok dalam gliserol 20\% dan sebagian lagi digunakan untuk percobaan berikutnya yang disimpan dalam media agar miring LA.

Seleksi bakteri AQS pendegradasi AHL. Seleksi isolat bakteri $\mathrm{AQS}$ dilakukan dengan menggunakan biosensor Chromobacterium violaceum sebagai marker anti QS pada media LA (McClean et al., 1997). C. violaceum merespons rantai pendek AHL dengan memproduksi pigmen ungu violacein yang dikontrol oleh QS dan senyawa Anti QS yang dihasilkan suatu organisme akan menghambat produksi violacein dari C. violaceum (Morohoshi et al., 2008; McClean et al., 1997).

Metode disc diffusion. Isolat-isolat bakteri AQS yang telah murni ditumbuhkan pada media Luria Broth (LB). Setelah 48 jam kultur disentrifus pada 10.000 g selama sepuluh menit. Sebanyak $100 \mu \mathrm{L}$ supernatan diteteskan pada kertas cakram yang diletakkan di atas media LA dicawan yang mengandung biosensor C. violaceum (umur 16-18 jam). Menurut Bauer et al. (1966), standar pengujian untuk mendeteksi aktivitas anti QS adalah dengan metode disc diffusion menggunakan kertas cakram (diameter $6 \mathrm{~mm}$ ). Sebagai kontrol negatif digunakan media LB steril. Cawan diinkubasi pada suhu $28^{\circ} \mathrm{C}$ selama 24 jam untuk melihat penghambatan produksi warna ungu $C$. violaceum, penghambatan QS terdeteksi oleh adanya cincin tidak berwarna ungu di sekitar disk, tapi masih adanya sel yang viable oleh bakteri AQS. Pengukuran dilakukan dari tepi luar dari disk ke tepi zona hambat anti QS. Tidak terbentuknya warna ungu menunjukkan bahwa isolat menghasilkan anti $Q S$.

Identifikasi biokimia dan fisiologi bakteri AQS. Isolat bakteri $\mathrm{AQS}$ yang positif menghasilkan anti QS diidentifikasi berdasarkan perbedaan karakteristik secara fisiologi dan biokimia dengan pengujian hidrolisis terhadap gula-gula dengan API $50 \mathrm{CHB}$. Data sifat biokimia dan fisiologi bakteri yang diperoleh dianalisis secara deskriptif dan dibandingkan dengan standar deskripsi dalam Bergey's Manual of Determinative Bacteriology (Bergey \& Holt, 1994).

Identifikasi dan sekuensing gen 16S rDNA. DNA genom dari bakteri AQS diekstraksi dengan metode Gentra Puregene Yeast/Bact. Kit (Qiagen). Amplifikasi $16 \mathrm{~S}$ rDNA dengan menggunakan primer oligonukleotida spesifik prokariot yakni 63f (5'-CAG GCC TAA CAC ATG CAA GTC-3') dan 1387r (5'-GGG CGG WGT GTA CAA GGC-3') (Marchesi et al., 1998). Proses amplifikasi dengan siklus PCR, pradenaturasi (pre PCR) pada suhu $95^{\circ} \mathrm{C}$ selama lima menit. Denaturasi pada suhu $92^{\circ} \mathrm{C}$ selama 30 detik, pelekatan (annealing) pada suhu $55^{\circ} \mathrm{C}$ selama 30 detik, dan perpanjangan (elongation) DNA pada $72^{\circ} \mathrm{C}$ selama satu menit. Siklus ini diulang hingga 30 kali, pemanjangan DNA (post PCR) pa- da suhu $72^{\circ} \mathrm{C}$ selama lima menit, dan penyimpanan (store) pada suhu $4^{\circ} \mathrm{C}$. Selanjutnya produk DNA yang dihasilkan disekuens menggunakan jasa perusahaan sekuensing $1^{\text {st }}$ Base Singapura. Hasil pengurutan DNA dibandingkan dengan data 16S rDNA dari Gene Bank.

Bakteri yang positif dapat mendegradasi QS, selanjutnya dideteksi keberadaan dari gen aiiA (Autoinducer Inactivation) homolog dengan amplifikasi sekuen gen tersebut menggunakan PCR. Ekstraksi genom dari bakteri anti $Q S$ dengan menggunakan metode Gentra Puregene Yeast/ Bact. Kit (Qiagen).

Amplifikasi PCR dan sekuensing gen aiiA. Genom DNA yang sudah diperoleh selanjutnya diamplifikasi menggunakan GoTaq Green mastermix (Promega). Komponen reaksi PCR untuk total volume $25 \mathrm{~mL}$ terdiri atas $12,5 \mu \mathrm{L}$ buffer, nuclease free water $9 \mu \mathrm{L}$, masingmasing $1 \mu \mathrm{L}$ primer forward dan primer reverse. Sekuen primer yang digunakan adalah aiiAF (5'-ATGGGA TCCATGACAGTAAAGAAGCTTTAT-3') dan aiiAR (5'GTCGAATTCCTCAACAAGATACTCCTAATG-3'). Target amplifikasi PCR adalah 800 bp (Chan et al., 2009; Chu et al., 2011). Siklus untuk amplifikasi PCR gen aiiA dengan pradenaturasi pada suhu $94^{\circ} \mathrm{C}$ selama sepuluh menit, 35 siklus untuk denaturasi pada suhu $94^{\circ} \mathrm{C}$ (30 detik), annealing $52^{\circ} \mathrm{C}$ (30 detik), pemanjangan $72^{\circ} \mathrm{C}$ (satu menit); dan suhu pada final $72^{\circ} \mathrm{C}$ selama lima menit. Untuk mengetahui kemiripan gen aiiA pada bakteri anti QS, dilakukan sekuensing dari produk PCR yang positif mengandung gen aiiA menggunakan jasa perusahaan sekuensing $1^{\text {st }} B a s e$ Singapura. Hasil sekuen disejajarkan dengan data gen aiiA dari GeneBank menggunakan program Basic Local Alignment Search Tool-Nucleotida translation protein (BLAST-X).

\section{HASIL DAN BAHASAN}

\section{Isolat Bakteri Anti Quorum Sensing (AQS)}

Sebanyak 347 isolat bakteri telah berhasil diisolasi dari sampel usus ikan, sedimen, dan air kolam ikan lele. Hasil uji menggunakan bakteri indikator Chromobacterium violaceum diperoleh 68 isolat (19\%) yang memiliki aktivitas AQS (Tabel 1). Isolat yang memiliki aktivitas degradasi AHL (Acyl Homoserine Lactone) ditandai dengan terbentuknya zona yang tidak berwarna ungu di sekitar paperdisk yang ditetesi dengan supernatan isolat bakteri yang diuji. Hal ini menandakan bahwa isolat bakteri tersebut menghasilkan senyawa ekstraseluler penghambat produksi pigmen violacein berwarna ungu dari $C$. violaceum yang dihasilkan dari proses Quorum Sensing. Penghambatan QS yang mengatur produksi violacein pada $C$. violaceum melibatkan senyawa AHL dan berperan sebagai molekul signal. Penghambatan QS tersebut salah satunya disebabkan oleh aktivitas enzim laktonase (penghidrolisis molekul $\mathrm{AHL}$ ) yang dihasilkan oleh isolat $\mathrm{AQS}$. 
Tabel 1. Asal dan jumlah isolat bakteri AQS hasil isolasi dari sedimen, air kolam pemeliharaan, dan saluran pencernaan ikan lele

Table1. Sources and number of AQS bacterial isolates isolated from pond sediment, water, and the digestive tract

\begin{tabular}{|c|c|c|c|c|}
\hline \multicolumn{3}{|c|}{ Sampel (Sample) } & \multirow{2}{*}{$\begin{array}{c}\text { Isolat hasil } \\
\text { isolasi } \\
\text { Result of isolates }\end{array}$} & \multirow{2}{*}{$\begin{array}{c}\text { Jumlah isolat bakteri AQS } \\
\text { Number of } A Q S \text { bacterial } \\
\text { isolates }\end{array}$} \\
\hline Asal (Origin) & Sumber (Source) & $\begin{array}{c}\text { Jumlah } \\
\text { Total }\end{array}$ & & \\
\hline \multicolumn{5}{|l|}{ Parung: } \\
\hline - Kolam (Pond) 1 & $\begin{array}{l}\text { Organ pencernaan } \\
\text { Digestive tract }\end{array}$ & 5 & 27 & 3 \\
\hline \multirow{5}{*}{ - Kolam (Pond) 2} & Sedimen (Sediment) & 3 & 20 & 7 \\
\hline & Air (Water) & 3 & 25 & 4 \\
\hline & $\begin{array}{l}\text { Organ pencernaan } \\
\text { Digestive tract }\end{array}$ & 5 & 12 & 2 \\
\hline & Sedimen (Sediment) & 3 & 24 & 5 \\
\hline & Air (Water) & 3 & 30 & 2 \\
\hline \multicolumn{5}{|l|}{ Ciampea: } \\
\hline - Kolam (Pond) 1 & $\begin{array}{l}\text { Organ pencernaan } \\
\text { Digestive tract }\end{array}$ & 5 & 11 & 1 \\
\hline \multirow{5}{*}{ - Kolam (Pond) 2} & Sedimen (Sediment) & 3 & 10 & 5 \\
\hline & Air (Water) & 3 & 32 & 7 \\
\hline & $\begin{array}{l}\text { Organ pencernaan } \\
\text { Digestive tract }\end{array}$ & 5 & 10 & 1 \\
\hline & Sedimen (Sediment) & 3 & 23 & 3 \\
\hline & Air (Water) & 3 & 10 & 2 \\
\hline \multicolumn{5}{|l|}{ Gunung Sindur: } \\
\hline - Kolam (Pond) 1 & $\begin{array}{l}\text { Organ pencernaan } \\
\text { Digestive tract }\end{array}$ & 5 & 19 & 2 \\
\hline \multirow{6}{*}{ - Kolam (Pond) 2} & Sedimen (Sediment) & 3 & 26 & 6 \\
\hline & Air (Water) & 3 & 22 & 6 \\
\hline & $\begin{array}{l}\text { Organ pencernaan } \\
\text { Digestive tract }\end{array}$ & 5 & 8 & 1 \\
\hline & Sedimen (Sediment) & 3 & 15 & 5 \\
\hline & Air (Water) & 3 & 23 & 4 \\
\hline & Jumlah (Total) & 66 & 347 & 68 \\
\hline
\end{tabular}

Zona degradasi yang dihasilkan isolat hasil isolasi berkisar dari $2 \mathrm{~mm}$ sampai $20 \mathrm{~mm}$. Isolat TS2 memiliki AQS yang paling tinggi karena menghasilkan zona AQS terbesar $(20 \mathrm{~mm})$, kemudian disusul oleh isolat TS1, TA 23, dan TY 33 yaitu $18 \mathrm{~mm}, 16 \mathrm{~mm}$, dan $16 \mathrm{~mm}$. Sehingga dari ke-68 isolat AQS telah diperoleh empat isolat yang berpotensi sebagai AQS dengan luas zona yang ditunjukkan pada Gambar 1 dan Tabel 2.

\section{Identifikasi Isolat AQS Pendegradasi AHL}

Hasil identifikasi berdasarkan uji biokimia dan fisiologi menunjukkan bahwa keempat isolat bakteri $A Q S$ bersifat Gram positif, motil, membentuk spora, positif untuk uji oksidase, katalase, koloni berwarna krem pada TS 1 \& TA 23, dan putih untuk TS2 \& TY
33. Bakteri dapat tumbuh dengan baik pada suhu $30^{\circ} \mathrm{C}$, $37^{\circ} \mathrm{C}$, dan $40^{\circ} \mathrm{C}$ (TS 1 , TS 2 , dan TY 33), tetapi untuk TA 23 bakteri tidak tumbuh pada suhu $40^{\circ} \mathrm{C}$. Hasil penelitian ini sama dengan yang dilakukan oleh Mahakarnchanakul (1999). Isolat bakteri juga dapat tumbuh pada $\mathrm{NaCl}$ dengan konsentrasi $2 \%$, $4 \%$, dan 10\% seperti yang dilakukan oleh Chu et al. (2011), Mahakarnchanakul \& Beuchat (1999). Karakteristik isolat TS 1, TS 2, TY 33, dan TA 23 dalam menggunakan berbagai jenis gula (API $50 \mathrm{CHB}$ ) dapat dilihat pada Tabel 3. Berdasarkan sifat karakteristik biokimia ini yang telah dibandingkan dengan standar deskripsi menggunakan Bergey's Manual of Determinative Bacteriology, keempat isolat tersebut adalah kemungkinan mirip dengan Bacillus sp. 

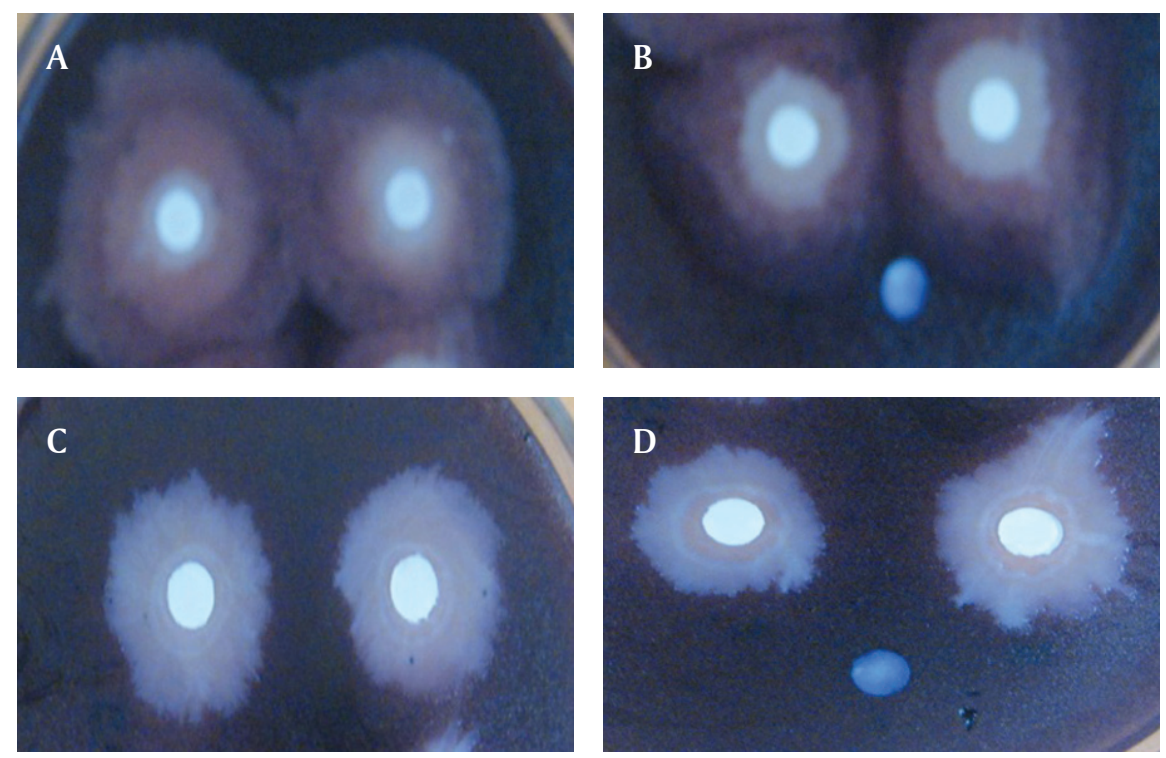

Gambar 1. Aktivitas Anti Quorum Sensing (AQS) dari isolat TS 2 (A), TS 1 (B), TA 23 (C), dan TY 33 (D)

Figure 1. Anti Quorum Sensing (AQS) activity of isolates TS 2 (A), TS 1 (B), TA 23 (C), and TY $33(D)$

Tabel 2. Diameter zona degradasi AHL oleh empat isolat bakteri AQS yang terpilih dengan zona hambat yang luas

Table 2. Diameter of AHL degradation zone of four selected AQS bacterial isolates with a wide inhibition zone

\begin{tabular}{|c|c|c|c|}
\hline \multirow{3}{*}{$\begin{array}{l}\text { Kode isolat } \\
\text { Isolate code }\end{array}$} & \multicolumn{3}{|c|}{$\begin{array}{c}\text { Diameter zona degradasi } \mathrm{AHL} \\
\text { Diameter of } A H L \text { degradation zone }(\mathrm{mm})\end{array}$} \\
\hline & \multicolumn{2}{|c|}{ Ulangan (Replication) } & \multirow{2}{*}{$\begin{array}{l}\text { Rataan } \\
\text { Average }\end{array}$} \\
\hline & 1 & 2 & \\
\hline TS 1 & 19 & 17 & 18 \\
\hline TS 2 & 20 & 20 & 20 \\
\hline TA 23 & 16 & 16 & 16 \\
\hline TY 33 & 16 & 16 & 16 \\
\hline
\end{tabular}

\section{Identifikasi dan Sekuensing Gen 16S rRNA}

Hasil amplifikasi gen 16S rRNA pada isolat TS 1 , TS 2, TA 23, dan TY 33 menunjukkan pita amplikon 1.500 bp ditunjukkan pada Gambar 4. Berdasarkan hasil analisis sekuen 16S rRNA, isolat TS1 menunjukkan kedekatan dengan Bacillus amyloliquefaciens dengan indeks kemiripan 93\%, isolat TS 2, dan TY 33 masingmasing menunjukkan kedekatan dengan Lysinnibacillus sphaericus dan Lysinnibacillus fusiformis dengan indeks kemiripan 99\%. Isolat TA 23 menunjukkan kedekatan dengan Bacillus cereus dengan indeks kemiripan $100 \%$. Sekuen gen 16S rRNA yang memiliki identitas kemiripan kurang dari 97\% memiliki kemungkinan terindikasi sebagai novel spesies (Stackebrandt \& Goebel, 1994;
Drancourt et al., 2000). TS1 memiliki indikasi sebagai novel spesies karena sekuens DNA ini memiliki identitas maksimum kemiripan < 97\% yaitu 93\%. Pohon filogenetik yang menunjukkan kekerabatan isolat ini dengan beberapa spesies bakteri yang ada di basis data dapat dilihat pada Gambar 2 dan Tabel 4.

\section{Gen aiiA dari Isolat Bakteri Uji}

Hasil amplikasi gen aiiA dengan PCR menunjukkan bahwa keempat isolat yaitu: TS 1, TS 2, TA 23, dan TY 33 memiliki gen aiiA. Produk PCR dari gen aiiA berukuran 800 bp ditunjukkan pada Gambar 4. Hasil ini sesuai dengan yang dikemukakan dalam penelitian Chu et al. (2011), menghasilkan amplikon PCR sebesar 800 bp dari isolat bakteri AQS yang diisolasi dari tanah. Hasil analisis sekuen gen aiiA dengan BLAST$\mathrm{X}$, dari keempat isolat tersebut menunjukkan gen aiiA homolog dengan AHL laktonase bakteri Bacillus thuringiensis dan Bacillus cereus dengan tingkat kemiripan 78\%, 99\%, dan 100\% (Tabel 5, Gambar 3). AHL lactonase atau disebut juga dengan AHL hydrolase (Feng Liu et al., 2013; Liu et al., 2005) telah digunakan sebagai bakteri QQ atau AQS untuk mendegradasi AHL dari suatu bakteri patogen sehingga dapat melemahkan faktor virulensinya. Penggunaan bakteri AHL laktonase merupakan strategi yang menjanjikan untuk mencegah dan mengendalikan infeksi dan virulensi bakteri patogen melalui mekanisme anti-QS, serta berpotensi untuk dikembangkan sebagai salah satu alternatif pengendalian bakteri patogen.

Data yang disajikan di sini menunjukkan bahwa AHL laktonase yang dikodekan oleh gen aiiA pada 
Tabel 3. Hasil uji fisiologi dan biokimia untuk karakterisasi isolat $\mathrm{AQS}$

Table 3. Results of physiological and biochemical tests for characterization of AQS isolates

\begin{tabular}{|c|c|c|c|c|c|c|c|c|c|}
\hline \multirow{2}{*}{$\begin{array}{l}\text { Karakteristik } \\
\text { Characteristics }\end{array}$} & \multicolumn{4}{|c|}{ Isolat (Isolate) } & \multirow{2}{*}{$\begin{array}{l}\text { Karakteristik } \\
\text { Characteristics }\end{array}$} & \multicolumn{4}{|c|}{ Isolat (Isolate) } \\
\hline & TS 1 & TS 2 & TA 23 & TY 33 & & TS 1 & TS 2 & TA 23 & TY 33 \\
\hline Reaksi (Reaction) Gram & + & + & + & + & Nacl $2 \%, 4 \%, 10 \%$ & + & + & + & + \\
\hline Bentuk (Shape) & B & B & B & B & $30^{\circ} \mathrm{C}$ & + & + & + & + \\
\hline Motilitas (Motility) & + & + & + & + & $37^{\circ} \mathrm{C}$ & + & + & + & + \\
\hline Oksidase (Oxidase ) & + & + & + & + & $40^{\circ} \mathrm{C}$ & + & + & - & + \\
\hline \multirow[t]{2}{*}{ Katalase (Catalase) } & + & + & + & + & Warna koloni & Krem & Putih & Krem & Krem \\
\hline & & & & & Colony color & Cream & White & Cream & Cream \\
\hline API 50 CHB & TS 1 & TS 2 & TA 23 & TY 33 & API $50 \mathrm{CHB}$ & TS 1 & TS 2 & TA 23 & TY 33 \\
\hline Glycerol & + & + & + & - & Salicin & + & + & + & + \\
\hline Erythrithol & - & - & + & - & Allobiose & + & + & + & + \\
\hline D-arabinose & - & + & + & + & Maltose & + & + & + & + \\
\hline L-arabinose & + & - & + & + & Lactose & + & + & + & + \\
\hline Ribose & + & + & + & + & Melibiose & - & - & + & + \\
\hline D-xylose & - & + & + & + & Saccharose & + & + & + & + \\
\hline L-xylose & - & - & + & - & Trehalose & + & + & + & + \\
\hline Adonithol & - & + & + & + & Inulin & - & - & - & - \\
\hline$\beta$-methyl-xyloside & - & - & + & - & Melezitose & - & - & - & - \\
\hline Galactose & - & + & + & + & D-raffinose & - & - & - & + \\
\hline D- glucose & + & + & + & + & Amidon & - & + & - & + \\
\hline L-fructose & + & + & + & + & Glycogene & - & + & - & + \\
\hline D-mannose & + & + & + & + & Zylitol & - & - & + & - \\
\hline L-sarbose & - & - & + & - & $\beta$-gentiobiose & + & + & + & + \\
\hline Rhamnos & - & + & + & + & D-furanose & - & + & - & - \\
\hline Dulcitol & - & - & + & - & D-lyxose & - & - & - & - \\
\hline Inositol & + & + & + & + & D-tagatose & - & - & - & - \\
\hline Mannitol & + & + & + & + & D-fucose & - & - & - & - \\
\hline Sorbitol & + & + & + & - & L-fucose & - & - & - & - \\
\hline$\alpha$-methyl-D-mannoside & - & + & + & - & D-arabitol & - & + & - & + \\
\hline$\alpha$-methyl-D-glucose & + & + & + & + & L-arabitol & - & - & - & - \\
\hline $\mathrm{N}$-acetyl-glucosamine & - & + & + & + & Gluconate & - & + & - & + \\
\hline Amygdalin & - & + & + & + & 2-keto-gluconate & - & - & - & - \\
\hline Arbutin & + & + & + & + & 5- keto-gluconate & - & - & - & - \\
\hline Esculin & + & + & + & + & & & & & \\
\hline
\end{tabular}

(-) Negatif (Negative); (+) Positif (Positive); B = Batang (Rod); AQS = Anti Quorum Sensing

keempat isolat adalah kandidat yang baik untuk dikembangkan lebih lanjut menjadi kandidat probiotik dengan melakukan seleksi lebih lanjut agar diperoleh kandidat probiotik potensial untuk pengendalian infeksi bakteri patogen pada budidaya ikan lele.

Berdasarkan analisis sekuen 16S rRNA, bakteri yang diisolasi tersebut, termasuk dalam golongan genus Bacillus sp. yang mempunyai kemampuan untuk memproduksi enzim laktonase. Produksi enzim ini diperlukan dalam proses degradasi AHL dan mampu menghambat violacein yang dihasilkan oleh bakteri dari Chromobacterium violaceum yang diregulasi oleh aktivitas QS (Chu et al., 2011). Konfirmasi enzim AQS dengan PCR yang menunjukkan bahwa bakteri yang diisolasi menghasilkan enzim laktonase (aiiA). Bakteri penghasil AHL dan bakteri pendegradasi AHL hidup berdampingan dalam setiap ekosistem, memiliki strategi yang berbeda untuk mendapatkan keuntungan kompetitif dalam ekosistem. Banyak bakteri pendegradasi AHL telah diisolasi dari tanah atau tanaman dan banyak digunakan sebagai biokontrol patogen tanaman. Aplikasi bakteri ini dapat mengganggu sistem QS bakteri penyakit. Gen aiiA dari Bacillus sp. telah dikloning ke tanaman tembakau dan kentang menjadi tanaman transgenik yang tahan penyakit (Dong et al., 2001). 


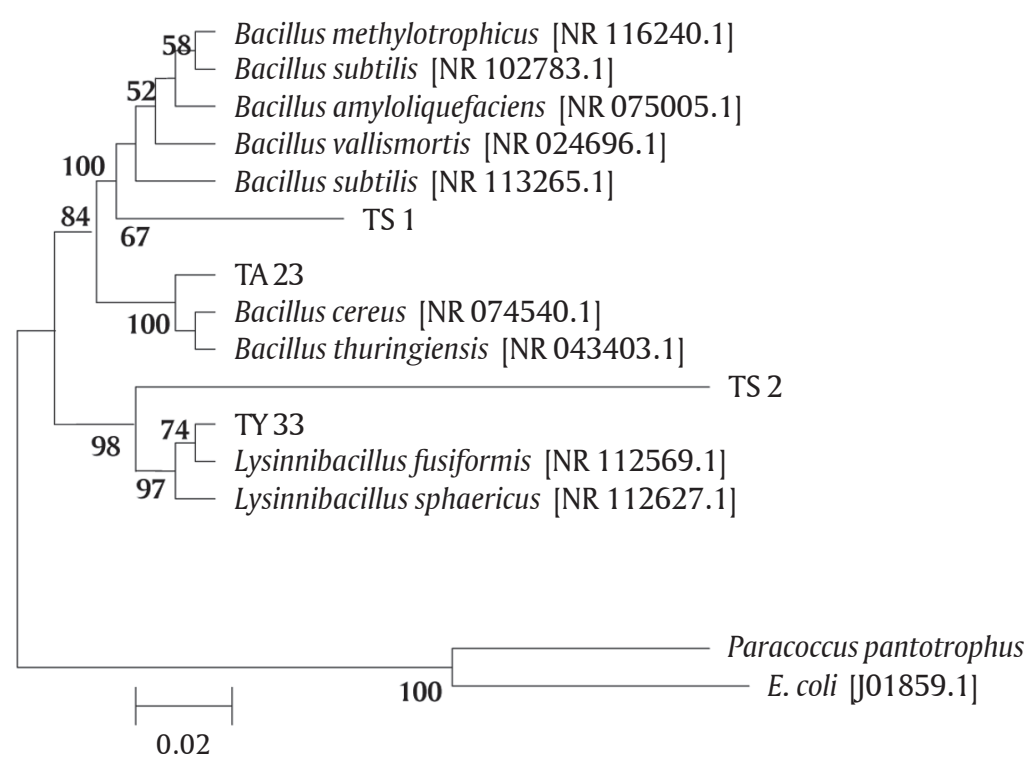

Gambar 2. Pohon filogenetik berdasarkan sekuen gen 16S rRNA yang menunjukkan hubungan kekerabatan antara bakteri AQS TS 1, TS 2, TA 23, dan TY 33 dengan kelompok bakteri Bacillus yang lain menggunakan metode Neighbor Joining (NJ) dengan bootstrap 1.000x

Figure 2. Phylogenetic tree based on $16 S \mathrm{~S} r R N A$ gene sequences showing the relationship between AQS TS 1, TS 2, TA 23, and TY 33 bacteria with other group of Bacillus using Neighbor Joining (NJ) method with 1,000x bootstrap

Tabel 4. Hasil analisis sekuen gen $16 \mathrm{~S}$ rRNA isolat TS 1, TS 2, TA 23, dan TY 33

Table 4. Sequence analysis results of $16 \mathrm{~S}$ rRNA gene of TS 1, TS 2, TA 23, and TY 33 isolates

\begin{tabular}{|c|c|c|c|}
\hline $\begin{array}{l}\text { Isolat } \\
\text { Isolate }\end{array}$ & $\begin{array}{l}\text { Homologi bakteri (Blast-N) } \\
\text { Bacterial homology (Blast- } N \text { ) }\end{array}$ & $\begin{array}{l}\text { Kemiripan } \\
\text { Similarity }(\%)\end{array}$ & $\begin{array}{c}\text { No. akses } \\
\text { Accession number }\end{array}$ \\
\hline TS 1 & $\begin{array}{l}\text { Bacillus amyloliquefaciens subsp. plantarum } \\
\text { strain FZB42 }\end{array}$ & 93 & NR 0750005.1 \\
\hline TS 2 & Lysinnibacillus sphaericus strain NBRC 15095 & 99 & NR 112627.1 \\
\hline TA 23 & Bacillus cereus strain ATCC 14579 & 100 & NR 074540.1 \\
\hline TY 33 & Lysinnibacillus fusiformis strain NBRC 15717 & 99 & NR 112569.1 \\
\hline
\end{tabular}

Tabel 5. Kemiripan sekuen protein dari fragmen gen aiiA dengan pusat data di Gene Bank menggunakan Basic Local Alignment Search Tool for Protein, using translated nucleotide (BLAST-X)

Table 5. Similarity of protein sequence of aiiA gene fragment compared with data base in Gene Bank using Basic Local Alignment Search Tool for Protein, using translated nucleotide (BLAST-X)

\begin{tabular}{llc}
\hline $\begin{array}{c}\text { Isolat } \\
\text { Isolate }\end{array}$ & \multicolumn{1}{c}{$\begin{array}{c}\text { Homologi protein (Blast-X) } \\
\text { Protein homology (Blast-X) }\end{array}$} & $\begin{array}{c}\text { Kemiripan } \\
\text { Similarity (\%) }\end{array}$ \\
\hline TS 1 & AHL lactonase aiiA (Bacillus cereus) & 78 \\
TS 2 & AHL hydrolase (Bacillus thuringiensis BMB171) & 99 \\
TA 23 & AHL hydrolase (Bacillus thuringiensis BMB171) & 100 \\
TY 33 & AHL hydrolase (Bacillus thuringiensis BMB171) & 100 \\
\hline
\end{tabular}

Aktivitas QS telah banyak ditemukan pada bakteri, baik Gram positif maupun Gram negatif, lebih dari 70 spesies bakteri Gram negatif menghasilkan acyl homoserine lactones (AHLs), yang berperan penting dalam regulasi ekspresi gen, termasuk gen-gen yang berperan dalam pembentukan biofilm dan faktor vi- 


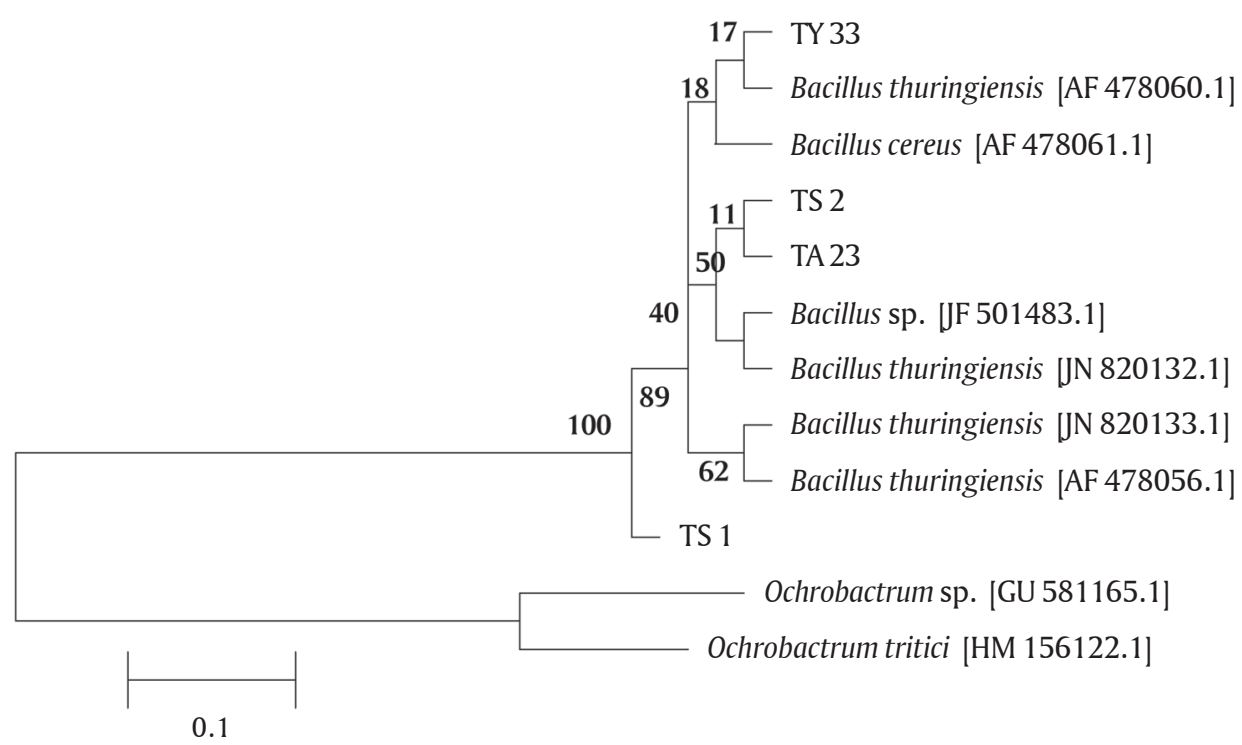

Gambar 3. Pohon filogenetik gen aiiA dari isolat TS 1, TS2, TY 33, TA 23 dibandingkan dengan bakteri penghasil laktonase lain menggunakan metode Neighbor Joining (NJ) dengan bootstrap 1.000x

Figure 3. Phylogenetic tree of aiiA genes from TS 1, TS 2, TY 33, TA 23 isolates compared with other bacteria laktonase using Neighbor Joining (NJ) method with bootstrap 1,000x

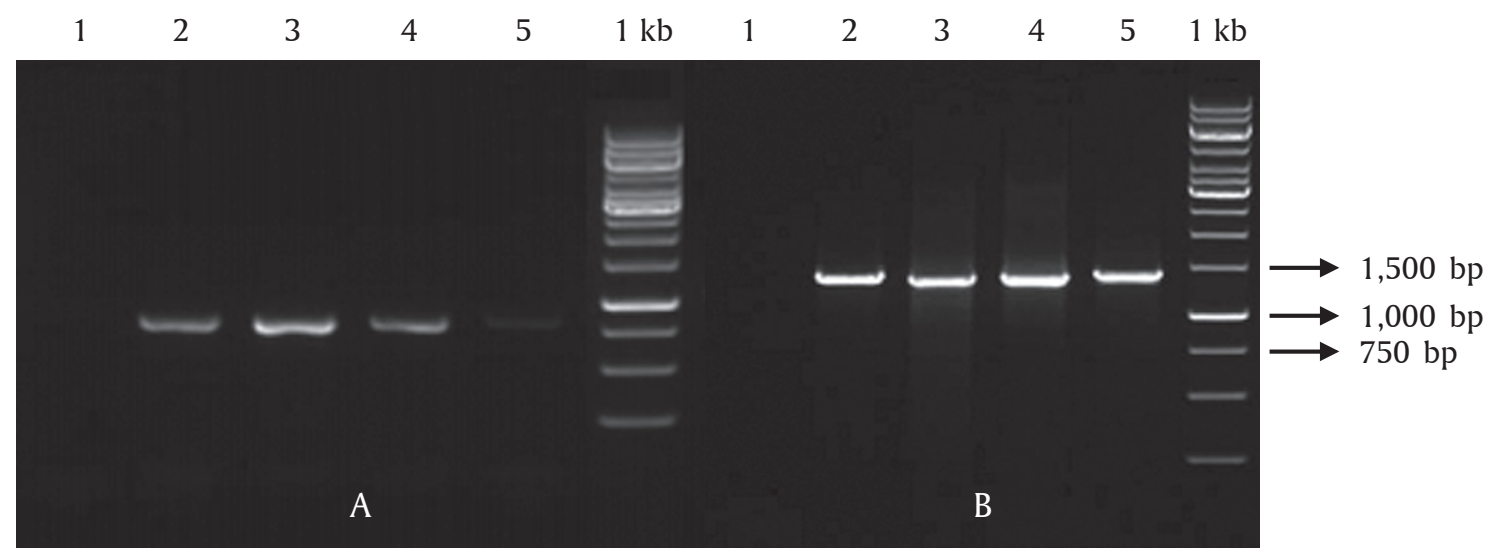

Gambar 4. Hasil amplifikasi PCR gen aiiA enzim laktonase (A) dan 16S rRNA (B). 1 = Negatif kontrol, $2=$ TS $1,3=$ TS 2, $4=$ TY 33, $5=$ TA 23, dan marker DNA ladder $1 \mathrm{~Kb}$

Figure 4. PCR amplification results of aiiA gene lactonase enzyme (A) and 16S rRNA gene (B). $1=$ Negative control, $2=T S 1,3=T S 2,4=T Y 33,5=T A 23$, and $1 \mathrm{~Kb}$ of (DNA ladder marker)

rulensi pada bakteri patogen (Bhargava et al., 2010; Wang et al., 2013). Upaya untuk mengganggu Quorum Sensing dalam pembentukan biofilm dan faktor virulensi memungkinkan mengidentifikasi molekul dengan kemampuan untuk mengganggu sistem QS (Kalia \& Purohit, 2011; Huma et al., 2011; Kalia, 2013). Dua enzim yaitu asil-homoserine lakton laktonase (AHL lactonase) dan asil-homoserine lakton asilase (AHL asilase), diketahui dapat mendegradasi molekul AHL dengan menghidrolisis cincin lakton dan reaksi pemotongan ikatan peptide. AHL laktonase adalah metalo-enzim yang ditemukan pada Bacillus spp. di antaranya: $B$. cereus, B. mycoides, B. thuringiensis, dan spesies lainnya (Huma et al., 2011; Seo et al., 2011; Dong et al., 2000).
Penghambatan sistem Quorum Sensing pada bakteri patogen baru-baru ini telah disarankan sebagai strategi baru untuk digunakan dalam akuakultur (Defoirdt et al., 2011; Merrifield et al., 2010; Vine et al., 2006). Quorum Sensing adalah proses yang melibatkan komunikasi sel ke sel bakteri dengan berat molekul sinyal yang rendah dan memperoleh respons bergantung pada kepadatan populasi dari bakteri. Molekul sinyal AHL (N-asil homoserine lakton) dan/ atau $\mathrm{Al}-2$ (autoinducer 2) telah ditemukan terlibat dalam pengaturan faktor virulensi dalam banyak bakteri patogen, termasuk patogen pada ikan (Defoirdt et al., 2006; Rasch et al., 2004). Bakteri yang mampu melemahkan molekul Quorum Sensing dapat dimanfaatkan sebagai agen biokontrol dalam akuakultur. Beberapa 
bakteri akuatik telah banyak diteliti untuk Anti Quorum Sensing (Chu et al., 2011; Merrifield et al., 2010; Nakayama et al., 2009). Bacillus laut, Halobacillus salinus menghasilkan Quorum Quenching untuk mengganggu sistem Quorum Sensing dari Vibrio harveyi (Mustafa et al., 2011).

Senyawa Anti Quorum Sensing yang dihasilkan oleh bakteri dapat mengganggu Quorum Sensing tetapi tidak memengaruhi pertumbuhan bakteri patogen (Manefield et al., 1999). Sehingga kemungkinan pengembangan resistensi akan lebih kecil daripada penggunaan antibiotik konvensional. AQS dapat digunakan sebagai antipatogen (Hentzer \& Givskov, 2003). Senyawa anti patogenik tidak menimbulkan tekanan selektif untuk pengembangan resistensi dan dapat digunakan sebagai strategi biokontrol berkelanjutan, sehingga sintesis senyawa AQS bermanfaat untuk dapat diterapkan dalam mengendalikan patogen di budidaya ikan.

\section{KESIMPULAN}

Sebanyak empat isolat (TS 1, TS 2, TA 23, dan TY 33) telah berhasil diisolasi dan diseleksi memiliki aktivitas Anti Quorum Sensing. Keempat isolat tersebut menghasilkan AHL laktonase atau AHL hidrolase dan mampu mendegradasi AHL dari $C$. violaceum. Gen aiiA pada isolat tersebut telah terkonfirmasi dengan teknik amplifikasi menggunakan PCR. Berdasarkan sekuen gen 16S rRNA, isolat-isolat tersebut teridentifikasi sebagai Bacillus amyloliquefaciens, Lysinnibacillus sphaericus, Lysinnibacillus fusiformis, dan Bacillus cereus.

\section{UCAPAN TERIMA KASIH}

Ucapan terima kasih disampaikan kepada Balai Penelitian dan Pengembangan Perikanan Budidaya Air Tawar, Bogor dan Instalasi Penelitian dan Pengembangan Pengendalian Penyakit Ikan, Kementerian Kelautan dan Perikanan yang telah membantu kelancaran penelitian ini.

\section{DARTAR ACUAN}

Bauer, A.W., Kirby, W.M., Sherris, J.C., \& Turck, M. (1966). Antibiotic susceptibility testing by a standardized single disk method. Am. J. Clin. Pathol., 45(4), 493-496.

Bergey, D.H., \& Holt, J.G. (1994). Bergey's Manual of Determinative Bacteriology. Ed ke-9. Baltimore: Williams \& Wilkins.

Bhargava, N., Sharma, P., \& Capalash, N. (2010). Quorum sensing in Acinetobacter: an emerging pathogen. Crit Rev. Microbiol., 36, 349-360.

Chan, K.G., Yin, W.F., Sam, C.K., \& Koh, C.L. (2009). A novel medium for the isolation of $\mathrm{N}$-acylhomoserine lactone-degrading bacteria. J. Ind. Microbiol.
Biotechnol., 36, 247-251.

Chen, R., Zhigang, Z., Yanan, C., Yingguo, B., \& Bin, Y. (2010). High yield expression of an AHL-lactonase from Bacillus sp. B546 in Pichia pastoris and its application to reduce Aeromonas hydrophila mortality in aquaculture. Microbial Cell Fact., 9, 1-10.

Chu, W.H., Lu, F., Zhu, W., \& Kang, C.T. (2011). Isolation and characterization of new potential probiotic bacteria based on quorum-sensing system. J. Applied Microbiol., 110(1), 202-208.

Darshanee, Ruwandeepika, H.A., Defoirdt, T., Bhowmick, P.B., Karunasagar, I, Karunasagar, I., \& Bossier, P. (2011). In vitro and in vivo expression of virulence genes in Vibrio isolates belonging to the Harveyi clade in relation to their virulence towards gnotobiotic brine shrimp (Artemia franciscana). Environ. Microbiol., 13(2), 506-517.

Defoirdt, T., Boona, N., Bossierb, P., \& Verstraete, W. (2004). Disruption of bacterial quorum sensing: an unexplored strategy to fight infections in aquaculture. Aquaculture, 24069-88.

Defoirdt, T., Crab, R., Wood, T.K., Sorgeloos, P., Verstraete, W., \& Bossier, P. (2006). Quorum sensing-disrupting brominated furanones protect the gnotobiotic brine shrimp Artemia franciscana from pathogenic Vibrio harveyi, Vibrio campbellii and Vibrio parahaemolyticus isolates. Applied and Environmental Microbiology, 72, 6419-6423.

Defoirdt, T., Boon, N., Sorgeloos, P., Verstraete, W., \& Bossier, P. (2008). Quorum sensing and quorum quenching in Vibrio harveyi: lessons learned from in vivo work. ISME J, 2, 19-26.

Defoirdt, T., Sorgeloos, P., \& Bossier, P. (2011). Alternatives to antibiotics for the control of bacterial disease in aquaculture. Current Opinion in Microbiology, 14, 251-258.

Dong, Y., H JI, Xu XZ Li, \& Zhang H. (2000). AiiA, an enzymes that inactivates the acylhomoserine lactone quorum sensing signal and attenuates the virulence of Erwinia caratovora. Proc. Natl. Acad. Sci. USA, 97, 3526-3531.

Dong, Y.H., Wang, L.H., Xu, J.L., Zhang, H.B., Zhang, X.F., \& Zhang, L.H. (2001). Quenching quorumsensing-dependent bacterial infection by a $\mathrm{N}$-acyl homoserine lactonase. Nature, 411, 813-817.

Dong, Y.H., Wang, L.H., \& Zhang, L.H. (2007). Quorum-quenching microbial infections: mechanisms and implications. Philos Trans $R$ Soc Lond B Biol. Sci., 362, 1201-121.

Drancourt, M., Bollet, C., Carlioz, A., Martelin, R., Gayral, J.P., \& Raoult, D. (2000). 16S ribosomal sequence analysis of a large collection of environmental and clinical unidentifiable bacterial isolates. J. Clin. Microbiol., 38, 3623-3630. 
Feng Liu Ce, Dali Liu, Momb, J., Thomas, P.W., Lajoie, A., Petsko, G.A., Fast, W., \& Ringe, D. (2013). A Phenylalanine Clamp Controls Substrate Specificity in the Quorum Quenching Metallo- $\gamma$-lactonase from Bacillus thuringiensis. J. Biochem., 52, 16031610.

Hentzer, M., \& Givskov, M. (2003). Pharmacological inhibition of quorum sensing for the treatment of chronic bacterial infection. Journal of Clinical Investigation, 112, 1300-1307.

Henke, J.M., \& Bassler, B.L. (2004). Quorum sensing regulates type III secretion in Vibrio harveyi and Vibrio parahaemolyticus.J. Bacteriol., 186, 3794-3805.

Huma, N., Shankar, P., Kushwah, J., Bhushan, A., Joshi, J., Mukherjee, T., Raju, S., Purohit, H.J., \& Kalia, V.C. (2011). Diversity and polymorphism in AHLlactonase gene (aiiA) of Bacillus. J. Microbiol. Biotechnol., 21, 1001-1011.

Kalia, V.C., \& Purohit, H.J. (2011). Quenching the quorum sensing system: potential antibacterial drug targets. Crit. Rev. Microbiol., 37, 121-140.

Kalia, V.C. (2013). Quorum sensing inhibitors: an overview. Biotechnol. Adv., 224-245.

Liu, D., Lepore, B.W., Petsko, G.A., Thomas, P.W., Stone, E.M., Fast, W., \& Ringe, D. (2005). Threedimensional structure of the quorum-quenching $\mathrm{N}$-acyl homoserine lactone hydrolase from Bacillus thuringiensis. PNAS, 102, 11882-11887.

Mahakarnchanakul, W., \& Beuchat, L.R. (1999). Influence of temperature shifts on survival, growth, and toxin production by psychrotrophic and mesophilic strains of Bacillus cereusin potatoes and chicken gravy. International Journal of Food Microbiology, 47, 179-187.

Manefield, M., de Nys, R., Kumar, N., Read, R., Givskov, M., Steinberg, P., \& Kjelleberg, S. (1999). Evidence that halogenated furanones from Delisea pulchra inhibit acylated homoserine lactone (AHL)mediated gene expression by displacing the AHL signal from its receptor protein. Microbiology, 145, 283-291

Marchesi, J.R., Sato, T., Weightman, A.J., Marthin, T.A., Fry, J.C., Hiom, S.J., \& Wade, W.G. (1998). Design and evaluation of useful bacterium-spesifik PCR primers that amplify genes coding for bacterial 16S-rRNA. Appl. Environ. Microbiol., 64, 795799.

McClean, K.H., Winson, M.K., Fish, L., Taylor, A., Chhabra, S.R., Camara, M., Daykin, M., Lambr, J.H., \& Swift, S. (1997). Quorum sensing and Chromobacterium violaceum: exploitation of violacein production and inhibition for the detection of $\mathrm{N}$ acylhomoserine lactones. Microbiol., 143, 37033711 .
Merrifield, D.L., Bradley, G., Baker, R.T.M., Dimitroglou, A., \& Davies, S.J., (2010). Probiotic applications for rainbow trout (Oncorhynchus mykiss Walbaum) I. Effects on growth performance, feed utilisation, intestinal microbiota and related health criteria. Aqua. J., p. 1365-2095.

Morohoshi, T., Nakazawa, S., Ebata, A., Kato, N., \& Ikeda, T. (2008). Identification and Characterization of N-Acylhomoserine Lactone-Acylase from the Fish Intestinal Shewanella sp. Strain MIB015. Biosci. Biotechnol. Biochem., 72, 1887-1893.

Musthafa, K.S., Saroja, V., Pandian, S.K., \& Ravi, A.V. (2011). Antipathogenic potential of marine Bacillus sp. SS4 on Nacyl-homoserine-lactone-mediated virulence factors production in Pseudomonas aeruginosa (PAO1). In: J. of Biosciences, 36(1), 55-67.

Nakayama, T., Lu, H., \& Nomura, N. (2009). Inhibitory effects of Bacillus probionts on growth and toxin production of Vibrio harveyi pathogens of shrimp. In: Letters in Applied Microbiology, 49(6), 679-84.

Rasch, M., Buch, C., Austin, B., Slierendrecht, W.J., Ekmann, K.S., Larsen, J.L., Johansen, C., Riedel, K., Eberl, L., Givskov, M., \& Gram, L. (2004). An inhibitor of bacterial quorum sensing reduces mortality caused by vibriosis in rainbow trout (Oncorhynchus mykiss walbaum). Sistematic and Applied Microbiology, 24(3), 350-359.

Seo, M.J., Lee, B.S., Pyun, Y.R., \& Park, H. (2011). Isolation and characterization of $\mathrm{N}$-acylhomoserine lactonase from the thermophilic bacterium, Geobacillus caldoxylosilyticus YS-8. Biosci. Biotechnol. Biochem., 75,1789-1795.

Stackebrandt, E., \& Goebel, B.M. (1994). Taxonomic note: A place for DNA-DNA reassociation and $16 \mathrm{~S}$ rRNA sequence analysis in the present species definition in bacteriology. Int. J. Syst. Bacteriol., 44, 846-849.

Taga, M.E., Semmelhack, J.L., \& Bassler, B.L. (2001). The LuxS-dependent autoinducer AI-2 controls the expression of an $\mathrm{ABC}$ transforter that functions in AI-2 uptake in Salmonella typhimurium. Mol. Microbiol., (42), 77-93.

Vine, Niall, G.; Leukes, Winston, D., Kaiser, \& Horst. (2006). Probiotics in marine larviculture. In: FEMS Microbiology Reviews, 30(3), 404-27.

Wang, H., Tu, F., Gui, Z., Lu, X., \& Chu, W. (2013). Antibiotic resistance profiles and quorum sensing-dependent virulence factors in clinical isolates of Pseudomonas aeruginosa. Indian J. Microbiol., 53, 163-167.

You, J.L., Xue, X.L., Cao, L.X., Lu, X., Wang, J., Zhang, L.X., \& Zhou, S.N. (2007). Inhibition of Vibrio biofilm formation by a marine actinomycete strain. 